\title{
振り子・てこ型動吸振器を用いた構造物の震動制御 RESPONCE CONTROL OF STRUCTURES BY USING TUNED MASS DAMPER WITH LEVER AND PENDULUM MECHANISM
}

\author{
吉”村雄介*1, 山本鎮 男*2, 曾根 彰*3, 増田 新*4 \\ Yuusuke YOSHIMURA, Sizuo YAMAMOTO, Akira SONE and Arata MASUDA
}

This paper deals with both passive and active control of seismic response of structures such as buildings and towers by using a tuned mass damper with lever and pendulum mechanism. First, the tuning condition in optimum is analytically obtaind for this type of tuned mass damper and its performance is shown by several numerical analysis. Furthermore, the active control system of a tuned mass damper with lever and pendulum mechanism is applied to the multi-degree of freedom structure. It is shown that system can be effective for reducing the responce of multiple modes. Finally, it is proven that the displacement between the proposed tuned mass damper and the sructure using lever and pendulum mechanism can be one-fourth of that of conventional tuned mass damper.

Keywords : passive control, active control, tuned mass damper, pendulum, lever パッシブコントロール、アクティブコントロール、動吸振器、振り子、てこ

\section{1 緒 言}

近年、中高層の建築物等にTMD（動吸振器、Tuned Mass Damper）を設置し、風や小地震に対し、主として居住環 境の向上を目的としてパッシブまたはアクティブに制振を果た す試みがなされており、既に実績例が報告されている。

しかし在来の $T M D$ の機構は、大地震時の制震機構としては 不向きであるといわれている。それは、大地震時の大変形を建 物の質量の $0.5 \%$ 程度の小さな補助質量の運動エネルギーによっ て制振するためには、補助質量に大変位が発生を余義なくさせ るからである。そのために、大地震時には、建物と補助質量との 間に設置されるバネ・ダンパ一部分に大きなストローク（相対変 位）を生ずることとなり、その最大許容振幅は、巧みな設計を 施しても $1.5 \mathrm{~m}$ 程度が限度といわれている。従って、建物の約 $0.5 \%$ の補助質量の最大許容相対変位は約 $1.5 m$ であり、これか ら逆算すると、制震が可能な地表面の最大加速度は約 $50 \mathrm{gal}$ 程 度であり、大地震時の制震には不向きであるといわれている。
この点を改良した、筆者らが開発した振り子とてこ機能を用 いた $T M D^{(1)}$ は、動吸振器機構を大地震時の震動の制御に適用 する可能性を秘めたものと言える。

この振り子とてこ機能を用いた $L P-T M D$ (動吸振 器、Lever and Pendulum Type Mass Damper) は、在来型 の $T M D$ と比べて制震性能を同等にした場合でもバネ・ダンパー 部のストロークを $1 / 4$ に低減できるということを報告してきた。 (1) 言い換えれば、振り子とてこ機能を用いた $L P-T M D$ 、 地表面最大加速度が $50 \times 4=200 \mathrm{gal}$ 程度の強震時まで適用可 能であると言える。

本論文では、既報 ${ }^{(2)}$ の振り子とてこ機能を用いた $T M D$ の最 適形状モデルを基にして新たに運動方程式を導出し、最適調整 を行った。このモデルを用いて 1 自由度構造物に振り子とてこ 機能を用いた $L P-T M D$ を設置した状態でのパッシブの運動 性能を確認した。さらに、多自由度構造物に振り子とてこ機能 を用いた $L P-T M D$ を設置し、これにアクティブ制御を付加
*1 京都工芸繊維大学卫工芸学部機械システム工学科 元大学院生・修上 (工学)

*2 京都二芝㵶維大学“芸学部機械システム工学科 教授・工博

*3 京都工芸緎維大学工芸学部機械システム工学科 助教授・ 工博

*4 京都工芸繊維大学工芸学部機械システム工学科 教務具
Former Graduate Student, Dept, of Mechanical and System Engineering, Kyoto Institute of Technology, M. Eng.

Prof., Dept. of Mechanical and System Engineering, Kyoto Institute of Technology, Dr. Eng.

Assoc. Prof., Dept. of Mechanical and System Engineering, Kyoto Institute of Technology, Dr. Eng.

Assistant, Dept. of Mechanical and System Engineering, Kyoto Institute of Technology 
してパッシブ制振のターゲットモードを含めた複数の振動モ一 ドの制振を行ってその効果を検証し、この機構が大地震に適用 可能であることを示した。

2 振り子とてこ機能を用いた動吸振器によるパッシブコント ロール

本研究で用いる振り子とてこ機能を用いた動吸振器、 $L P-$ $T M D$ は、図 1 に示すようにレバー先端にのみ質量を有するバ ネつき振り子である。

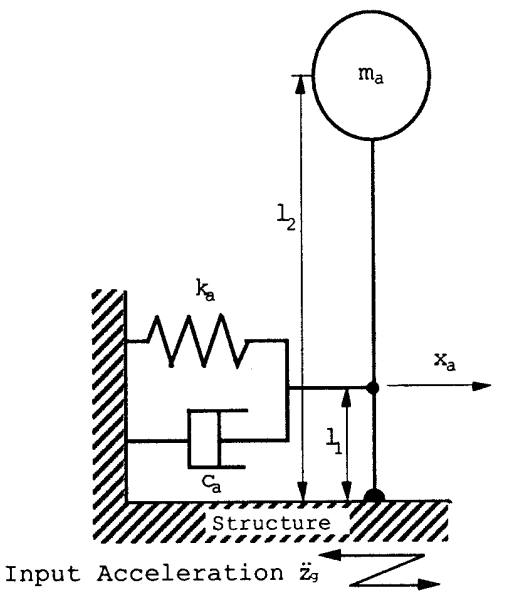

図 1 振り子とてこ機能を用いた動吸振器のモデル

$L P-T M D$ の最適調整を行う為に、在来型の $T M D$ の最適 調整に用いられる Den Hartog の $P Q$ 点理論 (1)(4)をここで も適用する。構造物の 1 次モード質量 $m_{1}$ と $L P-T M D$ の連 成運動方程式は、図 2 を参照すると次式のように書ける。

まず、振り子棒と建物の接合部（支点）に働く反力を $H_{L P}$ 、 てこ比 $\lambda=l_{2} / l_{1}$ として、質量 $m_{a}$ と $m_{1}$ について、ニュート ンの第 2 法則を適用すると、

$$
m_{a}\left(\ddot{z}_{g}+\ddot{x}_{1}+\lambda \ddot{x}_{a}\right)=-c_{a} \dot{x}_{a}-k_{a} x_{a}+H_{L P}
$$

$m_{1}\left(\ddot{z}_{g}+\ddot{x}_{1}\right)=-c_{1} \dot{x}_{1}-k_{1} x_{1}+c_{a} \dot{x}_{a}+k_{a} x_{a}-H_{L P}$

振幅 $x_{a}$ の基点においてモーメントの釣合をとると、

$$
-m_{a}\left(\ddot{z}_{g}+\ddot{x}_{1}+\lambda \ddot{x}_{a}\right)\left(l_{2}-l_{1}\right)-H_{L P} l_{1}=0
$$

ゆえに、

$$
H_{L P}=-m_{a}(\lambda-1)\left(\ddot{z}_{g}+\ddot{x}_{1}+\lambda \ddot{x}_{a}\right)
$$

これを式 (1) に代入して、 $\lambda \gg 1$ なることを考慮しつつ整理 すると次式を得る。

$$
m_{a} \lambda^{2} \ddot{x}_{a}+c_{a} \dot{x}_{a}+k_{a} x_{a}=-m_{a} \lambda\left(\ddot{z}_{g}+\ddot{x}_{1}\right)
$$

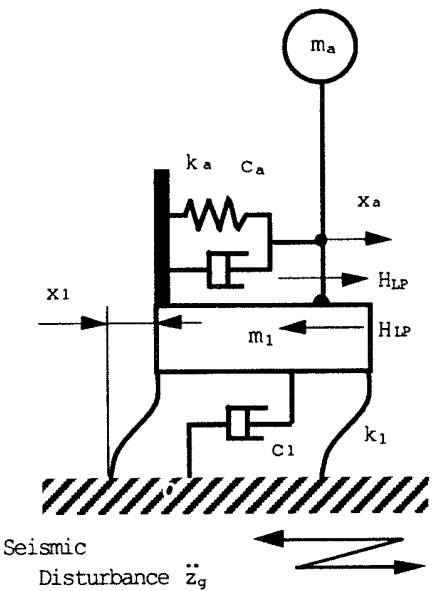

図 $2 L P-T M D$ と構造物の 1 次モード質量 $m_{1}$ との連成モ デル

一方、質点 $m_{a}$ にてモーメントの釣合をとると、

$$
\left(c_{a} \dot{x}_{a}+k_{a} x_{a}\right)\left(l_{2}-l_{1}\right)-H_{L P} l_{2}=0
$$

これより、

$$
H_{L P}=\frac{\lambda-1}{\lambda}\left(c_{a} \dot{x}_{a}+k_{a} x_{a}\right)
$$

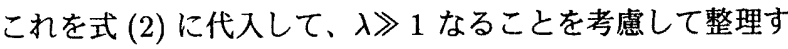
ると、

$m_{1} \ddot{x}_{1}+c_{1} \dot{x}_{1}+k_{1} x_{1}=-m_{1} \ddot{z}_{g}+\frac{1}{\lambda}\left(c_{a} \dot{x}_{a}+k_{a} x_{a}\right)$

ここに、

$m_{1}, c_{1}, k_{1}:$ 構造物の質量、减衰、バネ係数

$m_{a}, c_{a}, k_{a}: L P-T M D$ の質量、減衰、バネ係数

$\lambda:$ てこ比

$H_{L P}: L P-T M D$ の反力

入力を円振動数 $\omega$ 、振幅 $Z_{0}$ の正弦入力 $z_{g}=Z_{0} e^{i \omega t}$ とする と、構造物の減衰を無視すれば、構造物と $L P-T M D$ の応答 倍率はそれぞれ次式で求められる。

$$
\begin{aligned}
& \left|\frac{X_{1}}{X_{s t}}\right|=\sqrt{\frac{4 \zeta_{a}^{2} A+B}{4 \zeta_{a}^{2} C+D}} \\
& \left|\frac{X_{2}}{X_{s t}}\right|=\frac{\lambda}{\sqrt{4 \zeta_{a}^{2} C+D}}
\end{aligned}
$$

ただし、

$$
A=\{f g(1+\mu)\}^{2}
$$




$$
\begin{aligned}
B & =\left\{(1+\mu)\left(f^{2}-\lambda^{2} g^{2}\right)+\mu \lambda^{2} g^{2}\right\}^{2} \\
C & =\left\{f g\left(1-(1+\mu) g^{2}\right)\right\}^{2} \\
D & =\left\{\left(1-(1+\mu) g^{2}\right)\left(f^{2}-\lambda^{2} g^{2}\right)-\mu \lambda^{2} g^{4}\right\}^{2} \\
f & =\frac{\omega_{a}}{\omega_{1}}, \quad g=\frac{\omega}{\omega_{1}} \\
\omega_{1}^{2} & =\frac{k_{1}}{m_{1}}, \quad \omega_{a}^{2}=\frac{k_{a}}{m_{a}} \quad, \quad \zeta_{a}=\frac{c_{a}}{2 \sqrt{m_{a} k_{a}}} \\
x_{1} & =X_{1} e^{i \omega t}, \quad x_{a}=X_{a} e^{i \omega t} \\
X_{s t} & =m_{1} \omega^{2} Z_{0} / k_{1}
\end{aligned}
$$

$P Q$ 点理論より、最適な振動数比 $f$ と減衰比 $\zeta_{a}$ は、次のよ うに与えられる。

$$
\begin{gathered}
f^{2}=\frac{(2-\mu) \lambda^{2}}{2(1+\mu)^{2}} \\
\zeta_{a}^{2}=\frac{\mu \lambda^{2}}{8(1+\mu)}\left\{3+\frac{3 \mu \mp \sqrt{2 \mu}}{2-\mu}\right\}
\end{gathered}
$$

このとき、構造物の最大応答倍率は次式となる。

$$
\left|\frac{X_{1}}{X_{s t}}\right|_{\max }=\sqrt{\frac{2(1+\mu)^{2}}{\mu}}
$$

次に、 $L P-T M D$ の最適調整のパラメー夕を用いて、構造 物の応答倍率、および $T M D$ の応答倍率の共振曲線を図 3、図 4 に比較して示す。なお、最適条件を求める際には、構造物の 隇衰 $\zeta_{1}$ は無視したが、実際には構造物に滅衰が存在するので 最適条件に若干の誤差が生じる。しかしその量が僅少であるの で、最適条件は構造物の減衰を無視した場合のものを用い、応 答を求める場合には構造物の減衰を考慮するものとし、ここで は構造物の隇衰比 $\zeta_{1}=0.02$ とした。 $L P-T M D$ を用いた場 合、構造物に対する制振性能は在来型の $T M D$ を用いた場合と 同等に調整 (図 3) した時に、 $L P-T M D$ のストローク $x_{a}$ は在 来型 $T M D$ のほぼ $1 / 4$ 程度となっていることが分かる。(図 4)

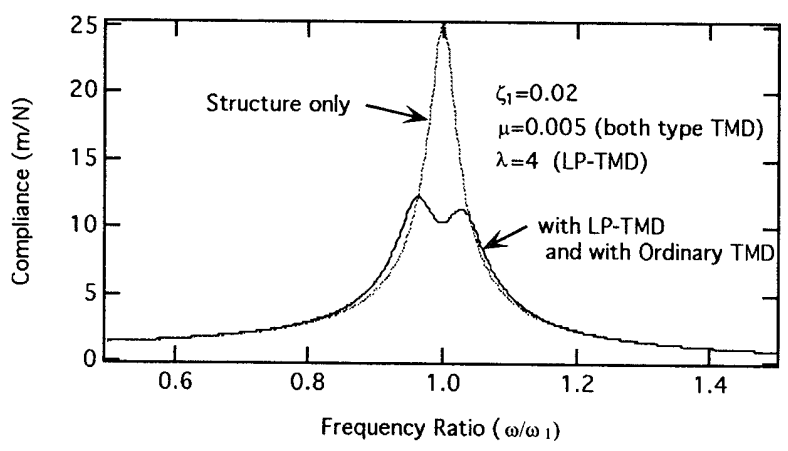

図 3 構造物の共振曲線

ここで用いた $L P-T M D$ てこ比は $\lambda=4$ の例である。

$L P-T M D$ の機構はてこ比 $\lambda$ を大きくすればするほどバネ・ 滅衰部のストロークを小さく抑えることができるので大地震時 の震動制御に使うことができると考えられる。しかしてこ比を 大きくしすぎるとレバーの弾性変形が無視できなくなる為、実 装にあたっては、レバーの弾性変形が生じない機構を考案する 必要がある。この方策については最後に触れることにする。

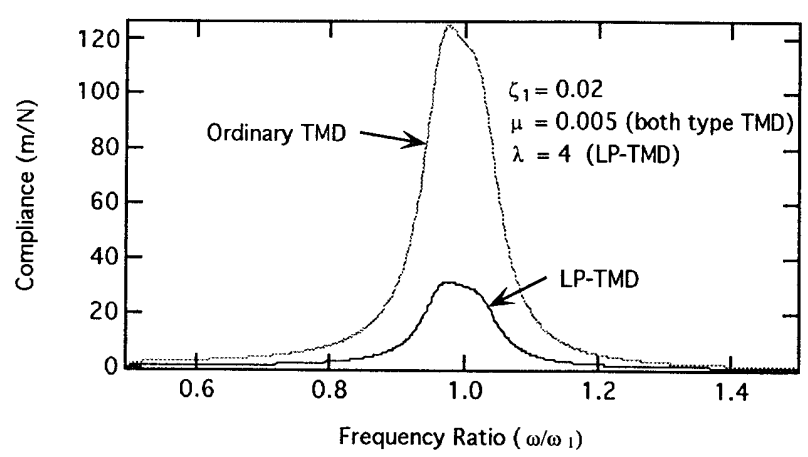

図 $4 T M D$ の共振曲線

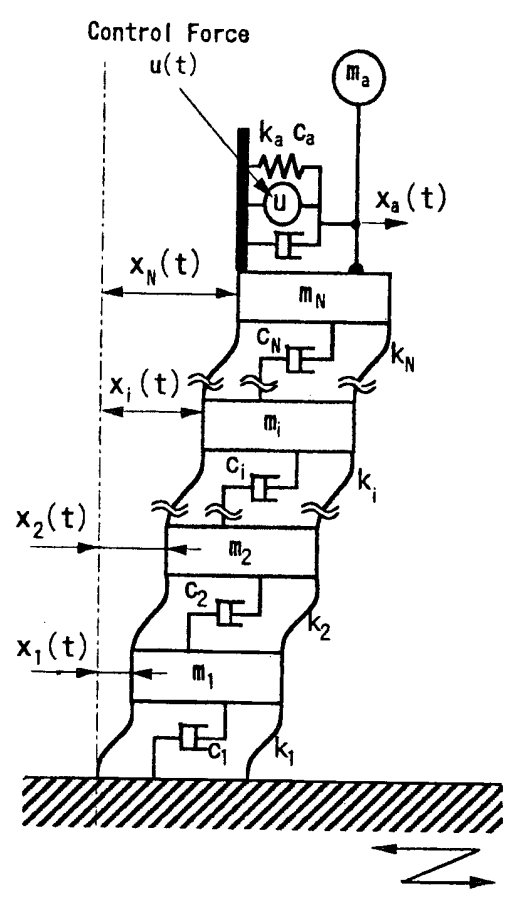

Seismic Disturbance $\ddot{z}_{g}(t)$

図 $5 \quad L P-T M D$ を設置した $N$ 自由度構造物

\section{3 構造物・動吸振器系のアクティブ制御}

前章で 1 次モード質量に対してパッシブに制御を行ったが、 実際の構造物の振動は複数の振動モ一ドを有し、入力地震波が $T M D$ のーゲットモード以外の振動モードの周波数帯域で卓 越する場合も充分予想できる。そこで、本章ではターゲットモ一 ドを含む複数の振動モードに対し、さらにアクティブ制御で応 答量を制御することを考える。

制御対象の構造物モデルとして、図 5 に示したような $N$ 質点 せん断モデルに $L P-T M D$ を設置したものを考える。ここで地 表面から $i$ 番目の質量 $m_{i}$ の地面との相対変位を $x_{i}(t)$ で表す。 入力地動加速度を $\ddot{z}_{g}(t)$ とし、振動制御のための制御力 $u(t)$ を $T M D$ のバネ・ダンパー部分に作用させる。この $N$ 質点モデル と $L P-T M D$ 運動方程式は、それぞれ次のように表される。

$$
\begin{aligned}
& \mathbf{M}_{s} \ddot{\mathbf{x}}_{s}(t)+\mathbf{C}_{s} \dot{\mathbf{x}}_{s}(t)+\mathbf{K}_{s} \mathbf{x}_{s}(t) \\
& =-\mathbf{m}_{g} \ddot{z}_{g}(t)+\mathbf{h}\left(c_{a} \dot{x}_{a}(t)+k_{a} x_{a}(t)+u(t)\right) \\
& m_{a} \lambda^{2} \ddot{x}_{a}(t)+c_{a} \dot{x}_{a}(t)+k_{a} x_{a}(t)
\end{aligned}
$$




$$
=-m_{a} \lambda\left(\ddot{x}_{N}(t)+\ddot{z}_{g}(t)\right)-u(t)
$$

ただし

$$
\mathbf{M}_{s}=\operatorname{diag}\left(m_{i}\right) \quad(i=1, \ldots, N)
$$

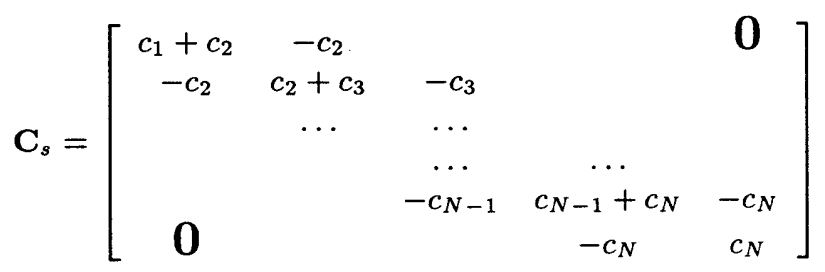

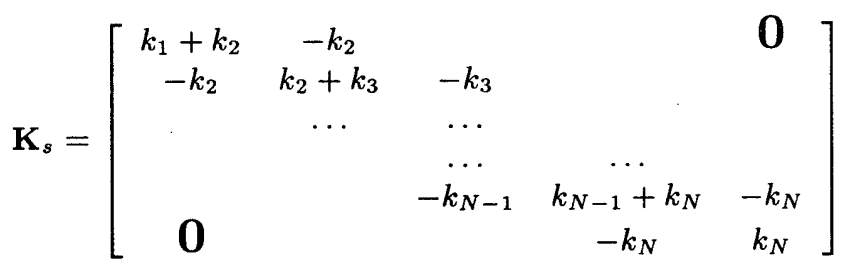
$\mathbf{m}_{g}=\left[\begin{array}{lll}m_{1} & \ldots & m_{N}\end{array}\right]^{T}, \mathbf{h}=\left[\begin{array}{llll}0 & \ldots & 0 & 1 / \lambda\end{array}\right]^{T}$ $\mathbf{x}_{s}(t)=\left[\begin{array}{lll}x_{1}(t) & \ldots & x_{N}(t)\end{array}\right]^{T}$

\section{ここで、 $(\cdot)^{T}$ は行列の転置を表わす。}

また、最上首質点 $m_{N}$ に関する運動方程式を用いて式 (15) から $\ddot{x}_{N}(t)$ を消去すると、次式を得る。

$$
\begin{gathered}
\ddot{x}_{a}(t)+\frac{c_{a}}{\lambda^{2}}\left(\frac{1}{m_{N}}+\frac{1}{m_{a}}\right) \dot{x}_{a}(t)+\frac{k_{a}}{\lambda^{2}}\left(\frac{1}{m_{N}}+\frac{1}{m_{a}}\right) x_{a}(t) \\
=\frac{1}{\lambda m_{N}}\left\{c_{N}\left(\dot{x}_{N}(t)-\dot{x}_{N-1}(t)\right)+k_{N}\left(x_{N}(t)-x_{N-1}(t)\right)\right\} \\
-\frac{1}{\lambda^{2}}\left(\frac{1}{m_{N}}+\frac{1}{m_{a}}\right) u(t)
\end{gathered}
$$

式 (14) 、式 (16) をまとめると、構造物・動吸振器系の運動 方程式が得られる。(5)

$$
\mathbf{M} \ddot{\mathbf{x}}_{f}(t)+\mathbf{C} \dot{\mathbf{x}}_{f}(t)+\mathbf{K} \mathbf{x}_{f}(t)=\mathbf{E} \ddot{z}_{g}(t)+\mathbf{F} u(t)
$$
ただし、

$$
\begin{aligned}
& \mathbf{M}=\left[\begin{array}{cc}
\mathbf{M}_{s} & \mathbf{0} \\
\mathbf{0} & 1
\end{array}\right], \mathbf{C}=\left[\begin{array}{ll}
\mathbf{C}_{s} & c_{12} \\
c_{21} & c_{22}
\end{array}\right] \\
& \mathbf{K}=\left[\begin{array}{ll}
\mathbf{K}_{s} & k_{12} \\
k_{21} & k_{22}
\end{array}\right], \quad \mathbf{E}=\left[\begin{array}{ll}
-\mathbf{m}_{g}^{T} & 0
\end{array}\right]
\end{aligned}
$$

$\mathbf{F}=\left[\mathbf{h}^{T}-\frac{1}{\lambda^{2}}\left(\frac{1}{m_{N}}+\frac{1}{m_{a}}\right)\right]^{T}, \mathbf{x}_{f}(t)=\left[\begin{array}{ll}\mathbf{x}_{s}^{T}(t) & x_{a}(t)\end{array}\right]^{T}$

$$
c_{12}=c_{a} \mathbf{h}, c_{21}=\left[\begin{array}{lllll}
0 & \ldots & 0 & \frac{c_{N}}{\lambda m_{N}} & -\frac{c_{N}}{\lambda m_{N}}
\end{array}\right]
$$$$
c_{22}=\frac{c_{a}}{\lambda^{2}}\left(\frac{1}{m_{N}}+\frac{1}{m_{a}}\right)
$$$$
k_{12}=k_{a} \mathbf{h}, k_{21}=\left[\begin{array}{llll}
0 & \ldots & 0 & \frac{k_{N}}{\lambda m_{N}}-\frac{k_{N}}{\lambda m_{N}}
\end{array}\right]
$$

$k_{22}=\frac{k_{a}}{\lambda^{2}}\left(\frac{1}{m_{N}}+\frac{1}{m_{a}}\right)$

式 (17) で構造物の変位ベクトルをモーダルマトリクス $\Phi_{s}$ と 基準座標 $\mathbf{q}_{s}(t)$ を用いて次式で表現する。

$$
\mathbf{x}_{s}(t)=\mathbf{\Phi}_{s} \mathbf{q}_{s}(t)
$$

ただし、

$$
\begin{gathered}
\boldsymbol{\Phi}_{s}=\left[\begin{array}{lll}
\boldsymbol{\Phi}_{1} & \ldots & \boldsymbol{\Phi}_{N}
\end{array}\right] \\
\mathbf{q}_{s}(t)=\left[\begin{array}{lll}
q_{1}(t) & \ldots & q_{N}(t)
\end{array}\right]^{T}
\end{gathered}
$$

ここで、 $\boldsymbol{\Phi}_{i}$ は $i$ 次モードのモードベクトルである。またモーダ ルマトリクス $\Phi_{s}$ は次式のように正規化されているとする。

$$
\boldsymbol{\Phi}_{s}^{T} \mathbf{M}_{s} \boldsymbol{\Phi}_{s}=\mathbf{I}_{N \times N}
$$

また、構造物の減衰量は小さく、次式が成立するものとする。

$$
\boldsymbol{\Phi}_{s}^{T} \mathbf{C}_{s} \boldsymbol{\Phi}_{s}=\Lambda_{\mathbf{S}}
$$

以上より式 (17) は次式となる。

$$
\ddot{\mathbf{q}}(t)+\Lambda \dot{\mathbf{q}}(t)+\boldsymbol{\Omega}^{2} \mathbf{q}(t)=\mathbf{e} \ddot{z}_{g}(t)+\mathbf{f} u(t)
$$

ただし、

$$
\begin{array}{ccc}
\mathbf{\Lambda}=\boldsymbol{\Phi}^{T} \mathbf{C} \boldsymbol{\Phi} & , \quad \boldsymbol{\Omega}^{2}=\boldsymbol{\Phi}^{T} \mathbf{K} \boldsymbol{\Phi} & , \quad \boldsymbol{\Phi}=\left[\begin{array}{cc}
\boldsymbol{\Phi}_{s} & 0 \\
\mathbf{0} & 1
\end{array}\right] \\
\mathbf{e}=\boldsymbol{\Phi}^{T} \mathbf{E} & , \quad \mathbf{f}=\boldsymbol{\Phi}^{T} \mathbf{F}, \quad \mathbf{q}(t)=\boldsymbol{\Phi}^{T} \mathbf{x}_{f}(t)
\end{array}
$$

前項で定式化した対象モデルに対し、最適レギュレータ理論 に基づいた $L Q$ 制御器を構成する。

まず、式 (21) を状態方程式に変形する。

$$
\dot{\mathbf{x}}(t)=\mathbf{A x}(t)+\mathbf{B} u(t)+\mathbf{d}_{g} \ddot{z}_{g}(t)
$$

$$
\begin{gathered}
\mathbf{A}=\left[\begin{array}{cc}
\mathbf{0} & \mathbf{I} \\
-\mathbf{\Omega}^{2} & -\boldsymbol{\Lambda}
\end{array}\right], \quad \mathbf{B}=\left[\begin{array}{l}
\mathbf{0} \\
\mathbf{e}
\end{array}\right] \\
\mathbf{d}_{g}=\left[\begin{array}{l}
\mathbf{0} \\
\mathbf{f}
\end{array}\right], \quad \mathbf{x}(t)=\left[\begin{array}{l}
\mathbf{q}(t) \\
\dot{\mathbf{q}}(t)
\end{array}\right]
\end{gathered}
$$

次に、最上層質点の絶対加速度 $\left\{\ddot{x}_{N}(t)+\ddot{z}_{g}(t)\right\}$ が出力とし て得られるものとすると、出力方程式は、次式で与えられる。

$$
y(t)=\mathbf{C x}(t)+\mathbf{D} u(t)+\mathbf{H}_{g} \ddot{z}_{g}(t)
$$

$$
\begin{aligned}
& \mathbf{C}=\left[\begin{array}{lllll}
0 & \ldots & 0 & 1 & 0
\end{array}\right] \boldsymbol{\Phi}\left[\begin{array}{ll}
-\boldsymbol{\Omega}^{2} & -\boldsymbol{\Lambda}
\end{array}\right] \\
& \mathbf{D}=\left[\begin{array}{lllll}
0 & \ldots & 0 & 1 & 0
\end{array}\right] \boldsymbol{\Phi} \mathbf{f}
\end{aligned}
$$


$\mathbf{H}_{g}=\left[\begin{array}{lllll}0 & \ldots & 0 & 1 & 0\end{array}\right] \mathbf{\Phi} \mathbf{e}+1$

また、 $L Q$ 制御器の設計にあたっては、式 (22)、式 (23) 中 の地動加速度 $\ddot{z}_{g}(t)$ を 0 として考えた。

今、制震性能と制御力の大きさのトレードオフを考え、次の 2 次評価規範を考える。

$$
J(u)=\int_{0}^{\infty}\left\{y^{2}(t)+r u^{2}(t)\right\} d t
$$

上式において、rは制御重み係数である。式 $(23)$ を用いると、 式 (24) は次式となる。

$$
J(u)=\int_{0}^{\infty}\left\{\mathbf{x}^{T}(t) \mathbf{Q} \mathbf{x}(t)+2 \mathbf{x}^{T}(t) \mathbf{N} u(t)+u^{T}(t) \mathbf{R} u(t)\right\} d t
$$

ただし、

$$
\mathbf{Q}=\mathbf{C}^{T} \mathbf{C} \quad, \quad \mathbf{N}=\mathbf{C}^{T} \mathbf{D} \quad, \quad \mathbf{R}=\mathbf{D}^{T} \mathbf{D}+r
$$

このとき、式 $(25)$ を最小にする最適制御力 $u^{o}(t)$ は次式で与 えられる。(6)

$$
u^{o}(t)=-\mathbf{K x}(t)
$$

ただし、

$$
\mathbf{K}=\mathbf{R}^{-1}\left(\mathbf{N}+\mathbf{B}^{T} \mathbf{P}\right)
$$

であり、行列 $\mathbf{P}$ は次の Riccati 型代数方程式の正定対称解 である。

$$
\mathbf{P A}+\mathbf{A}^{T} \mathbf{P}-(\mathbf{P B}+\mathbf{N}) \mathbf{R}^{-1}\left(\mathbf{B}^{T} \mathbf{P}+\mathbf{N}^{T}\right)+\mathbf{Q}=0
$$

しかし、式 (26) 中の状態変数は直接測定できないので、次式 で表わされる状態観测器（オブザーバー）（7)を構成する。

$$
\dot{\hat{\mathbf{x}}}(t)=\mathbf{A} \hat{\mathbf{x}}(t)+\mathbf{B} u(t)+\mathbf{K}_{o b}\{y(t)-\mathbf{C} \hat{\mathbf{x}}(t)-\mathbf{D} u(t)\}
$$

ここで、 $\mathbf{K}_{o b}$ はオブザーバーゲインである。そして、式 (28) から得られる状態変数 $\mathbf{x}(t)$ の推定值 $\hat{\mathbf{x}}(t)$ を用いて最適制御力 $u^{o}(t)$ を次式で与えるとする。

$$
u^{o}(t)=-\mathbf{K} \hat{\mathbf{x}}(t)
$$

以上のフローを図で表すと、図 6 となる。

4 数值シミュレーションによる制震性能結果

ここでは、数值実験用として 4 層の建築物を想定し、対象と

\begin{tabular}{|c|c|c|c|}
\hline \multicolumn{2}{|c|}{ Parameter } & \multicolumn{2}{|c|}{ Value } \\
\hline 構造物 & & & \\
\hline 質量 & $\begin{array}{l}\mathrm{m}_{1} \\
\mathrm{~m}_{2} \\
\mathrm{~m}_{3} \\
\mathrm{~m}_{4}\end{array}$ & $\begin{array}{l}2.0 \times 10^{4} \\
2.0 \times 10^{4} \\
1.5 \times 10^{4} \\
1.5 \times 10^{4}\end{array}$ & $\begin{array}{l}\mathrm{kg} \\
\mathrm{kg} \\
\mathrm{kg} \\
\mathrm{kg}\end{array}$ \\
\hline 㓮性 & $\begin{array}{l}k_{1} \\
k_{2} \\
k_{3} \\
k_{4}\end{array}$ & $\begin{array}{l}2.2 \times 10^{7} \\
2.1 \times 10^{7} \\
2.0 \times 10^{7} \\
2.0 \times 10^{7}\end{array}$ & $\begin{array}{l}\mathrm{N} / \mathrm{m} \\
\mathrm{N} / \mathrm{m} \\
\mathrm{N} / \mathrm{m} \\
\mathrm{N} / \mathrm{m}\end{array}$ \\
\hline モード減意比 & $\zeta_{i}(\mathrm{i}=1,2,3,4)$ & 0.02 & \\
\hline 固有振動数 & $\begin{array}{l}f_{1} \\
f_{2} \\
f_{3} \\
f_{4}\end{array}$ & $\begin{array}{r}2.0005 \\
5.3680 \\
8.3460 \\
10.2584\end{array}$ & $\begin{array}{l}\mathrm{Hz} \\
\mathrm{Hz} \\
\mathrm{Hz} \\
\mathrm{Hz}\end{array}$ \\
\hline 動收振器： & $\mu$ & 0.005 & \\
\hline てこ比 (LP-TMD) & $\lambda$ & 4 & \\
\hline
\end{tabular}
なる構造物を 4 質点せん断モデルとした。構造物の各パラメー タおよび動吸振器のパラメータを表 1 に示す。また、時刻歴シ ミュレーションにおいて時間刻みは $\Delta t=0.02 \mathrm{sec}$ とし、各初 期值はすべて 0 とした。

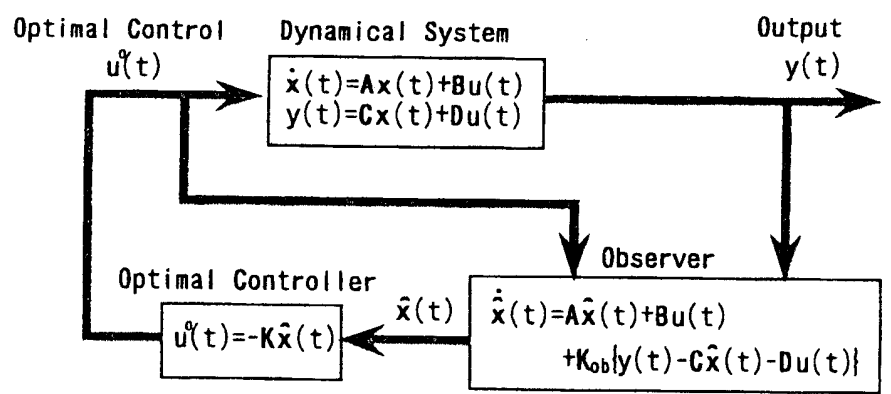

図 $6 L Q$ 制御システム

表 1 構造物・動吸振器のパラメータ

1 次の振動モードをターゲットモードとして、LP-TMD と在来型の $T M D$ についても同様に最適調整をほどこして、ま ずパッシブでの制震性能を両者比較検証する。

図 7 に地動加速度からパッシブ $T M D$ を設置した構造物の最 上層の絶対加速度への伝達関数のゲインを示す。この図より、2 章で述べたように、 $L P-T M D$ と在来型 $T M D$ が同等の制震 性能を持つように調整したことが確認される。この制震性能は、 てこ比を変化させても変わらないが、てこ比を上げると $T M D$ のストロークは図 8 に見られるように $L P-T M D$ 方がはる かに小さくなるのがわかる。

次に、入力を構造物の 2 次モードの周波数帯域で卓越成分を 持つ有色雑音を用いて、パッシブ $T M D$ を設置した構造物の応 答を図 9 に示す。図 9 より、パッシブ $T M D$ を設置した構造物 は、TMDを設置しない場合と比べてもあまり制振されていな い。これは $T M D$ を 1 次モードに対して最適調整しているので、 2 次モード以降に卓越成分を持つ地震入力が系に作用しても、 あまり $T M D$ の効果が現れないということを示している。そこ で 2 次モード以降をも制振するために、制御力を付加したアク ティブ $T M D$ を構成する。

3 章に基づいて $L Q$ 制御器を設計した。まずオブザーバーの 


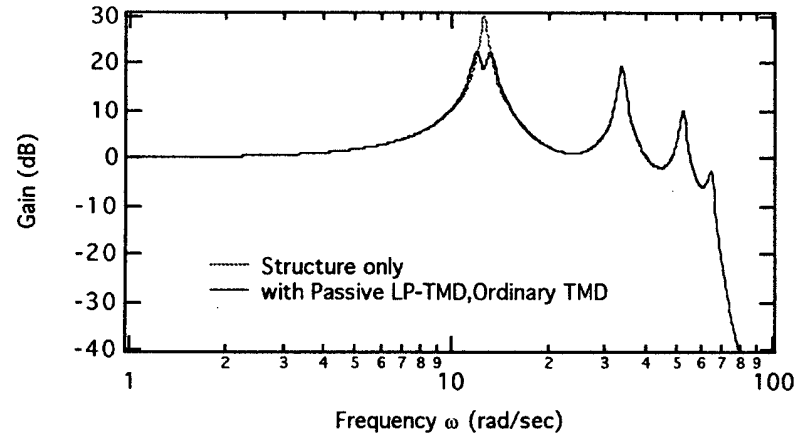

図 7 地動加速度からパッシブ $T M D$ を設置した構造物の最上 首質点の絶対加速度への伝達関数のゲイン

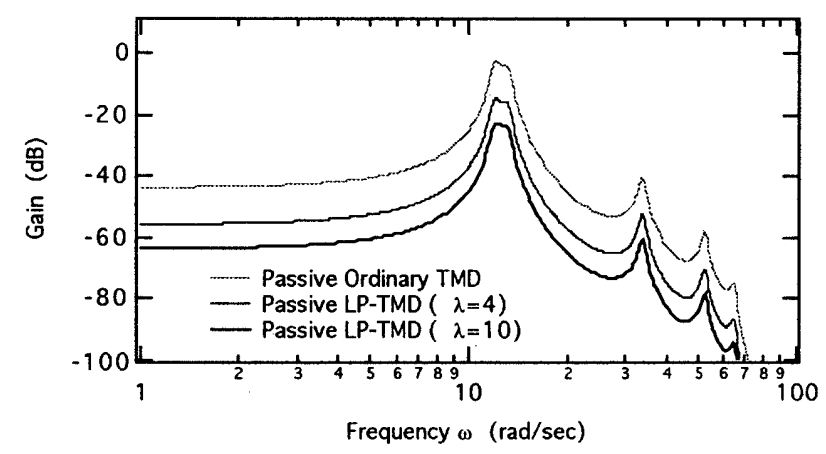

図 8 地動加速度からパッシブ $T M D$ のストロークへの伝達関 数のゲイン

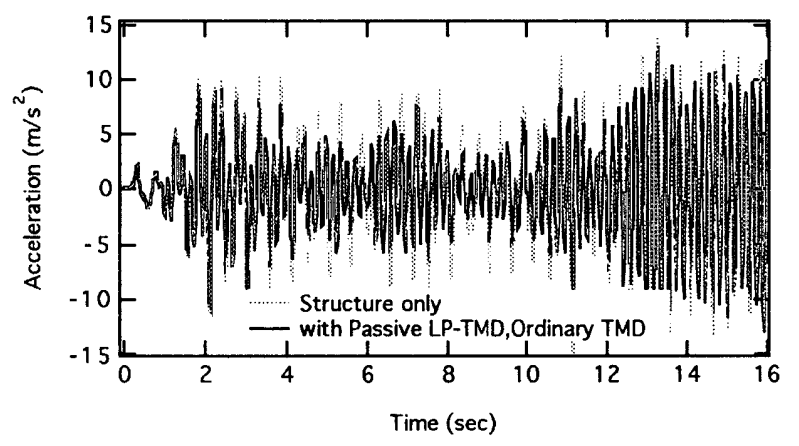

図 9 有色雑音入力に対するパッシブ $T M D$ を設置した構造物 の最上層の絶対加速度応答

設計にあたり、推定值 $\hat{\mathbf{x}}(t)$ が速やかに真值 $\mathbf{x}(t)$ に近づくよう に、オブザーバーの極すなわち $\left(\mathbf{A}-\mathbf{K}_{o b} \mathbf{C}\right)$ の固有值を、 $\mathbf{A}$ の固有値の $h$ 倍だけ虚軸から左側に遠ざけたものとした。こ こでは、制御重み係数 $r$ を在来型の $T M D$ で $r=1.6 \times 10^{8}$ 、 $L P-T M D$ で $r=1.0 \times 10^{9}$ 、オブザーバーの極の位置パラ メーター $h$ はいずれも $h=50$ としている。

まず、地動加速度からアクティブ $T M D$ を設置した構造物の 最上層質点の絶対加速度、TMDのストローク、制御力への伝達 関数のゲインをそれぞれ図 10、図 11、図 12 に示す。

これらの図より、当然ながらアクティブコントロールがパッ シブコントロールより有効に作用していることがわかる。アク ティブ $L P-T M D$ のストロークはパッシブと同様に、アクティ ブ TMDの 1/4 になっているが、制御力は逆に 4 倍になってい

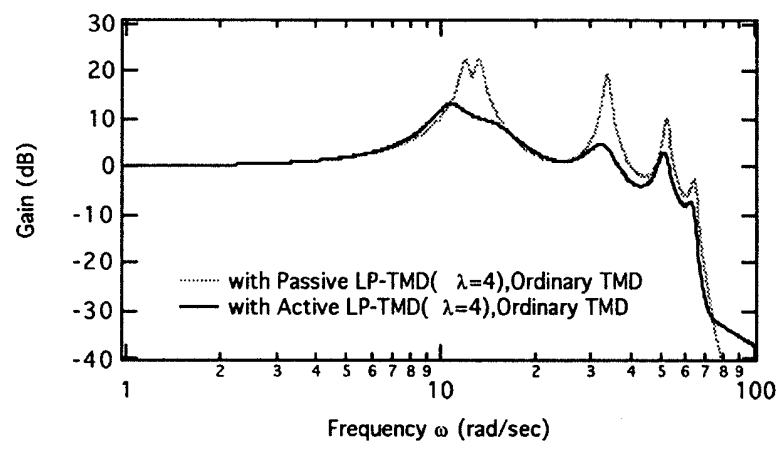

図 10 地動加速度からアクティブ $T M D$ を設置した構造物の最 上層質点の絶対加速度への伝達関数のゲイン

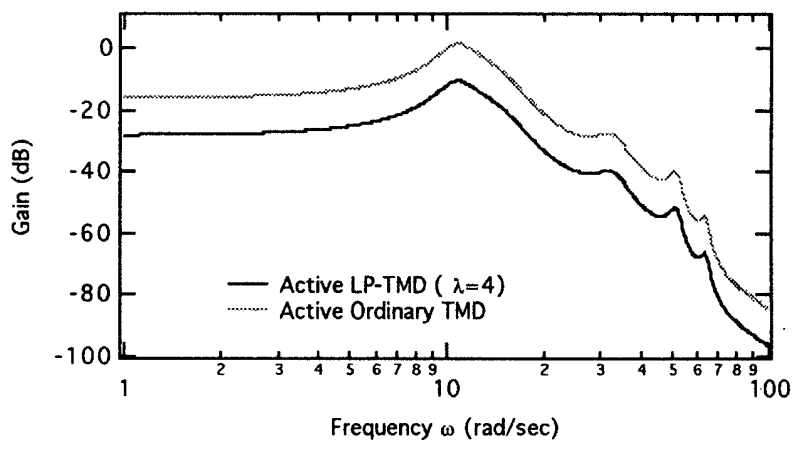

図 11 地動加速度からアクティブ TMDのストロークへの伝達 関数のゲイン

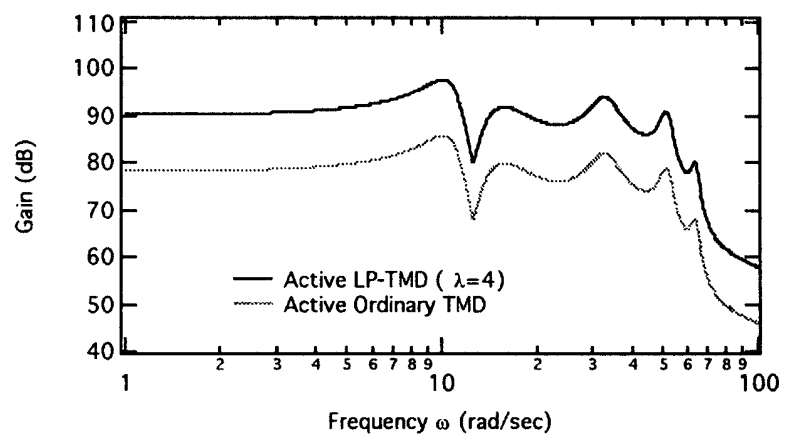

図 12 地動加速度から制御入力への伝達関数のゲイン

ることがわかる。

前述の有色雑音入力に対するアクティブ $T M D$ を設置した構 造物の応答と動吸振器のストロークを図 13 と図 14 に示す。図 13 をみると、図 9 に示したようにパッシブ状態ではあまり制振 できていなかったのが、アクティブ状態ではよく制振できてい ることが分かる。さらに図 14 より、アクティブ $L P-T M D$ の ストロークは、アクティブ $T M D$ の $1 / 4$ になっていることが 確認できた。

\section{5 実装置の機構の提案}

前章までで、 $L P-T M D$ 有効性を示すことができた。し かし、本機構の実装を考えた際に、レバー部分の軽量化、ある いはてこ比 $\lambda$ の増大に伴うレバー部分の弾性変形が無視できな くなると予想できる。そこで本章では、本機構の実現化への提 


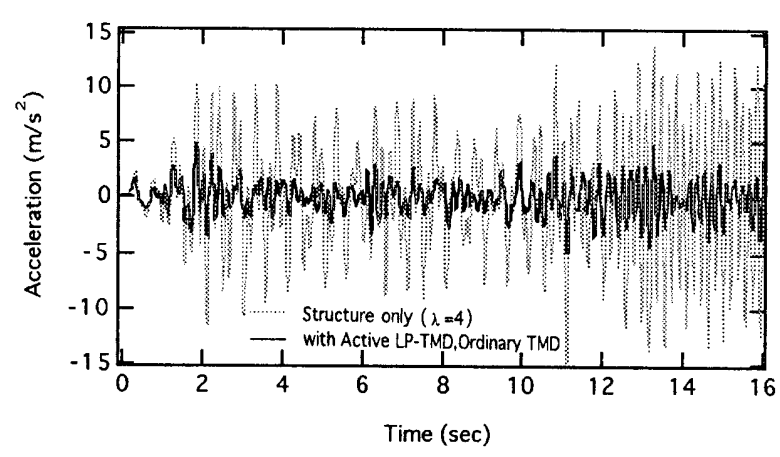

図 13 有色雑音入力に対するアクティブ $T M D$ を設置した構造 物の最上層の絶対加速度応答

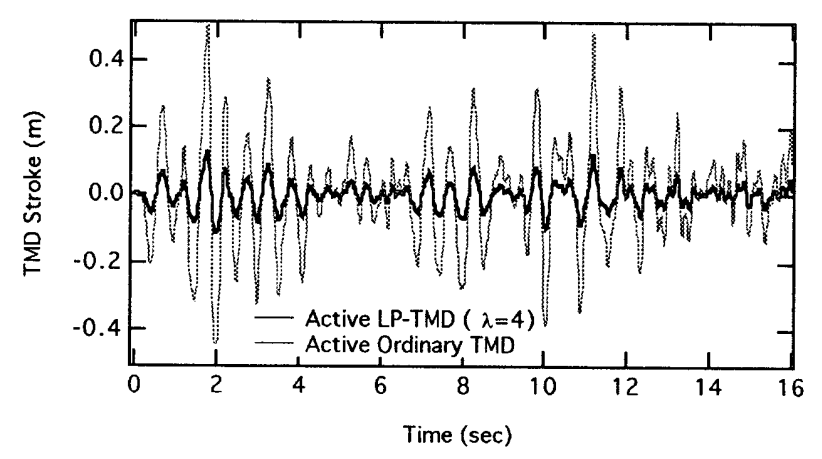

図 14 有色雑音入力に対するアクティブ $T M D$ を設置した構造 物の最上層の動吸振器のストローク

案を行う。

今回用いたモデルから $L P-T M D$ は、構造物に対する動吸 振器の質量比を在来型と等しくすると、制振性能が同じで、て こ比 $\lambda$ の設定により $T M D$ のストロークが在来型の $1 / \lambda$ 倍、制 御力は $\lambda$ 倍になることが分かった。このことから $L P-T M D$ は、動吸振器質量とバネ・ダンパー部の間に、バネ・ダンパー 部のストロークを $\lambda$ 倍に增幅して動吸掁器質量に伝える変位增 幅機構がついたものと考えることができる。そこで、その概念 図を図 15 と図 16 に示す。これらの図では、变位増幅機構とし てギアを想定している。この変位増幅機構の質量と回転慣性が 他に比べて微小で無視できると仮定すれば、これらの機構の運 動方程式もまた、本研究で取り扱った $L P-T M D$ 最適形状 モデルの運動方程式と一致する。最適形状の $L P-T M D$ の運 動方程式は微小回転内での運動を仮定しているが、この機構で はその仮定がないので実現には都合がよいと思われる。

\section{6 結言}

本研究では、本研究室で研究開発された振り子とてこ機能を 用いた動吸振器を最適形状化したモデルを用いて、パッシブお よびアクティブでの制震性能と特性を検証し、本機構が大地震 に適用できる動吸振器機構であることを示した。その結果、以 下のことが分かった。

（1）最適形状モデルの $L P-T M D$ の制震性能は、同じ質量比 の在来型のものと同じになった。

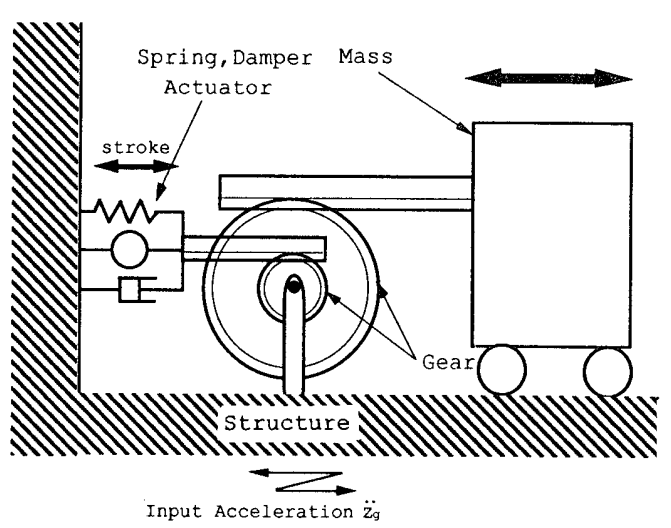

図 15 变位增幅機構付き動吸振器

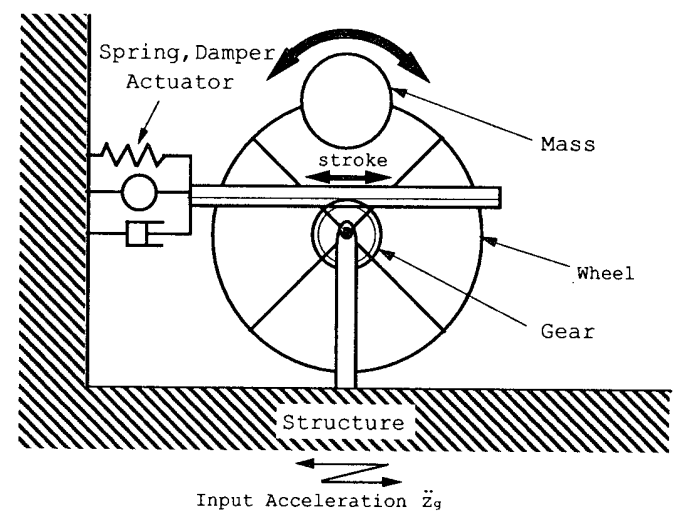

図 16 回転型動吸振器

（2）最適形状モデルの $L P-T M D$ のトロークは、在来型の $1 / \lambda$ に抑えられる。

（3）最適形状モデルの $L P-T M D$ に制御力を付加すると、制震 性能が同じならば制御力の大きさは在来型の $\lambda$ 倍である。

(4) 最適形状モデルの $L P-T M D$ は、バネ・ダンパー部の変 位を $\lambda$ 倍に增幅して動吸掁器質量に伝達する変位增幅機構 を、在来型の $T M D$ に付与したものとみなすことができる。 参考文献

1）藤波趾剛・山本鎮男：ふりことてこ機構を付与した動吸振器による 制振（機構の原理と最適調整），日本機械学会論文集（C 編），第 57 巻, 第 538 号, pp.1842 1847, 1991 年 6 月.

2）藤波健剛・山本鎮男・曾根彰：ふりことてこ機構を付与した動吸振 器による制振（パラメーターの最適設計），日本機械学会論文集 (C 編），第 57 巻，第 543 号, pp.3490 3496, 1991 年 11 月.

3）藤波健剛・山本鎮男・兽根彰：ふらことてこ機構を付与した動吸振 器による制振（外乱相殺制御による過渡応答特性の改善），アクティ ブ制震（振）シンポジウム論文集, pp.125〜130, 1992 年 3 月.

4）振動工学ハンドブック編集委員会編・(代表・谷口修) : 振動工学 ハンドブック, p.141, 盖賢堂, 1976 年.

5）野波健藏・西村秀和 他 1 名：アクティブ動吸振器を用いた多自由 度構造物の $H^{\infty}$ 制御（周波数重み関数の設計指針について）, 日 本機械学会論文集（C 編），第 58 巻，第 548 号, pp.1311 1317, 1992 年 4 月.

6) Katsuhiko Ogata : Modern Control Engineering (Second Edition), p.772, Prince Hall,New Jersey,1990.

7）伊藤正美：自動制御，p.145，丸善，1981 年. 